\author{
加熱条件の違いがもたらす \\ 離乳食に用いる粥の品質への影響 \\ 柴田(石渡)奈緒美・梅村詩音 \\ (岐皁大学教育学部)
}

（令和 2 年11月 25 日受付，令和 3 年 4 月 5 日受理）

\title{
The effects of different heating condition on the quality of rice porridge to use for the baby food
}

\author{
Naomi Shibata-Ishiwatari, Shion Umemura \\ Faculty of Education, Gifu University, 1-1, Yanagito, Gifu-shi, Gifu, 501-1193 \\ テ501-1193 岐阜県岐阜市柳戸 $1-1$
}

\begin{abstract}
We focused on three cooking methods of rice porridge that is the first solid food given to infants: "rice in a pot", "using the rice porridge mode on a rice cooker", and "cooked rice in a pot". The findings revealed that the gelatinization degree of all sample was about $95 \%$. "Using the rice porridge mode on a rice cooker" had the highest amount of amylose and reducing sugars in $1.0 \mathrm{~g}$ of rice porridge liquid, which was consistent with the properties at the end of cooking. The amount of reducing sugars produced was highest in the "cooked rice in a pot" since it took a long time to reach the deactivation temperature of the starch degrading enzyme. However, the concentrations of reducing sugars, amylose and eluted solids in the rice porridge liquid were lowest because i) water was added to cooked rice, which has low water absorbability; ii) the amount of added water was higher than other methods; and iii) the heating time in pot cooking after adding water was shorter. Because the heating time at $90^{\circ} \mathrm{C}$ or higher of "cooked rice in a pot" is shorter than other methods, it had the hardest rice grains. As shown above, even though all the heating conditions used in the present study were designed to make "jyubai-gayu", hardness and viscosity varied depending on heating conditions.
\end{abstract}

\section{1. 緒言}

2019 年の日本の出生数は過去最少の 86 万 5,239 人とな り ${ }^{1)}$, 少子化が大きな社会問題となっている。また三世 代世帯の割合が減少しているにもかかわらず2)，女性の 就業率は増加していることから ${ }^{3)}$, 今後, 今まで以上に 子育て世帯への支援が求められるであろう。子育てに関 する悩みは子どもの年齢に伴い変化するが, 平成 27 年度 乳幼児栄養調査 ${ }^{4)}$ より, 生後 6 か月頃から始まる離乳食 に関して約 $74.1 \%$ 保護者が何らかの悩みを抱えている
ことが報告されており，なかでも「作るのが負担，大変」 と回答した割合は全体の $33.5 \%$ と最も高かった。そこで 筆者らは, 離乳食の中でつぶし粥を対象とし, 調理者へ の科学的根拠に基づく知識の提供と, 乳児の食の安心 ・ 安全の貢献に向けた研究を行っている。

離乳開始時のつぶし粥は一般的に10倍粥と呼ばれる。 10倍粥の名称は, 乳児が口の中でつぶすことができるこ とを目的とし, 生米 1 に対して10倍量の水で調製するこ とに由来するが, 近年では炊飯器や電子レンジなどの家 電製品を利用した調理方法も普及しているため ${ }^{5)}$, 調理 
条件によっては生米に対して使用する水の量は10倍とは 限らない。しかし, すべての10倍粥の調理方法の共通点

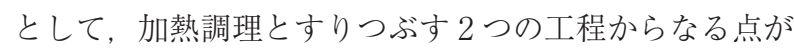
挙げられる。そのため, 分析を行う際は加熱調理方法と すりつぶし方の違い，それぞれの側面から整理する必要 がある。张に関する研究は, 加熱時の昇温速度の違いに 上る物理的, 化学的性状や官能評価への影響 ${ }^{6)}$, アミロー ス含有量の異なる米に扔けるテクスチャーの違い7)など, 多数報告されているが8-15), これらの粥の調製は生米を 鍋で加熱する方法を採用している報告が多い。現在は炏 飯器を用いた方法が離乳食作りの主流となっているた $め^{5)}$, 現在の離乳食作りを反映した加熱条件を研究対象 にする必要があると考えられる。そこで本稿では，10倍 归の作り方として20年前と2019年に扔いて利用率が高 かった「生米を鍋で調理する」と「炊飯器で炊いたご飯 を鍋で調理する」,そして, 2019年に利用率が高かった「炏 飯器の㧍粥モードで炊く」の 3 種類の加熱条件 ${ }^{5}$ を対象 とし，10倍粥を想定した離乳食に用いる粥の品質の違い について整理した内容を報告する。

\section{2. 実験方法}

\section{（1）10倍粥を想定した離乳食に用いる粥の加熱条件の}

\section{選定}

10倍粥の加熱条件は, 本や近年, 普及している SNS やインターネットに掲載されているレシピをもとに決定 した ${ }^{16-20)}$ 。

\section{1) 試料および調理器具}

試料には無洗米（令和元年, 岐阜県産コシヒカリ）を 用い, すべての加熱条件に扔いて一度の調理に生米を $75 \mathrm{~g}$ に水を加え, $23.2 \pm 0.2^{\circ} \mathrm{C}$ で30分間浸漬させた後, 加熱を開始した。一般的に米飯や邪を調理する際，加熱 過程で吹きこぼれないよう文化鍋や土鍋が使用されるこ とが多い。しかし，離乳食でつぶし䛍を調理するレシピ では鍋が使用されていたことから, 調理器具は IH 対応 ダイヤモンドコートパン鍋（底面 $160 \mathrm{~mm}$, 高さ $80 \mathrm{~mm}$ アイリスオーヤマ侏）と，ガラス蓋（直径 $180 \mathrm{~mm}$, ア イリスオーヤマ(侏) を使用した。なお，加熱過程におい て腒が吹きこぼれないことを予備実験で確認した。炊飯 器は IH 炊飯ジャー (JKU-A 型, タイガー魔法瓶(侏), 加熱機器は火力を 6 段階に設定できる IH コンロ（IHKTK 3，アイリスオーヤマ(侏) を使用した。

\section{2 ) 加熱条件}

「生米を鍋で調理する」(以後,「鍋」と記す）は，調 查をしたすべてのレシピに扔いて 16,17,19,20)，10倍粥の名称 の由来通り生米 1 に対して10倍量の水を用いること, 沸 騰するまで強火で加熱し，蓋をずらして弱火で加熱した 後，10分間蒸らすことが共通していた。そこで本研究で は, 生米 $75 \mathrm{~g}$ に水 $750 \mathrm{~g}$ 加えて浸漬させた後, 蓋をして 強火に相当する火力 $6(1400 \mathrm{~W})$ で 6 分間加熱し沸騰 させた。沸騰後は蓋を $30 \mathrm{~mm}$ 横にずらし，弱火に相当
する火力 2 (200W) で40分間加熱後, 消火した。なお 消火と同時に再度蓋をし，10分間蒸らした。

「炊飯器で㧍㛀を調理する」(以後, 「炊飯器」と記す) についても，調査をしたすべてのレシピにおいて，10倍 粥の名称の由来通り生米 1 に対して10倍量の水を用いて いた。そこで生米 $75 \mathrm{~g}$ に水 $750 \mathrm{~g}$ 加えて浸漬させた後, 炊飯器にプログラミングされている抒粥モードで炊飯し た。

「炊飯器で炊いたご飯を鍋で調理する」(以後，「炊飯 器十鍋」と記す）に扔いて米飯を鍋で加熱する工程は, 「鍋」と同様に沸騰するまで強火で加熱をすること，そ の後, 蓋をずらして弱火で加熱すること, 蒸らすことが すべてのレシピで共通していた。また米飯を鍋で加熱す る際には水を加える必要がある。加水量の違いは調理後 の品質に影響を及ぼすことが予想されたため，炊いた米 飯を鍋で加熱する粥のレシピを調査した。その結果，10 倍䉼を想定した離乳食に用いる粥では, 米飯の重量 1 に 対して $5 \sim 6$ 倍量の水を加えていた ${ }^{18-20) 。 な か て ゙ も ， ~} 5$ 倍量の水を用いた方法が最も多かったことから ${ }^{18-20)}$ ，本 研究は米飯を鍋で加熱する際は, 米飯の重量 1 に対して 5 倍量の水を加えることにした。以上の調査をもとに, 「炊飯器 + 鍋」は以下に決定した。まず生米 $75 \mathrm{~g}$ に水 $112 \mathrm{~g}$ 加えて浸漬後, 白米・無洗米モードで炊飯し, $160.2 \pm 2.8 \mathrm{~g}$ の米飯（水分含量 $61.5 \pm 1.1 \%$ ）を調理した。 その後, 鍋に米飯と水 $800 \mathrm{~g}$ を加えて蓋をし, 強火に相 当する火力 $6(1400 \mathrm{~W})$ で 5 分半加熱した。沸騰後は 蓋を $30 \mathrm{~mm}$ 横にずらし，弱火に相当する火力 $2(200 \mathrm{~W})$ で10分間加熱後，消火した。なお消火と同時に再度蓋を し，10分間蒸らした。

すべての加熱条件において，調理終了後，ただちに試 料をステンレス製の容器に移し, プラスチックフィルム をした。その後, ユニバーサルデザインフード自主規 格 ${ }^{21)}$ の測定温度を参考とし, 試料の中心温度が20.5 $1.9^{\circ} \mathrm{C}$ になるまで $20^{\circ} \mathrm{C}$ に設定した恒温槽（DO-600FA， アズワン(陎) で静置し，以降に示す実験に使用した。

\section{（2）粥飯および继液の分離}

十分に攪拌した濑 $100 \mathrm{~g}$ を, 直径 $180 \mathrm{~mm}$, 目開き $500 \mu \mathrm{m}$ のステンレス製ふるいの上に均一の厚さに広げ, 5 分間放置した。その後, 分離された液の重量を測定し た。以後，分離された液を郘液，ふるいの上に残った試

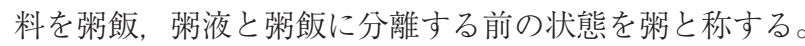
測定は, 5 回ずつ繰り返し行った。

\section{（3）離乳食に用いる继の品質測定 \\ 1 ) 温度履歴}

測定にはシース型熱電対（直径 $1.0 \mathrm{~mm}$ ）をデータロ ガー (LR8431，日置電機株) に取り付け，5秒ごとに 測定した。挿入位置は, 炊飯器は炊飯釜底中央から $10 \mathrm{~mm}$ 上部の位置に，鍋は鍋底中心から $20 \mathrm{~mm}$ 上部の 
位置とした。測定は, 各試料 5 回ずつ繰り返し行った。

\section{2) 糊 化 度}

粥を液体窒素で急速凍結後，日本食品分析センターに 糊化度の算出を依頼した。なお，分析方法にはグルコア ミラーゼ第 2 法 ${ }^{22}$ を採用した。測定は, 各試料 5 回ずつ 繰り返し行った。

\section{3) 含 水率}

粥および粥飯 $3.0 \mathrm{~g}$ を $105^{\circ} \mathrm{C} に$ 設定した恒温槽（DO600FA，アズワン(株)）を用いて24時間乾燥させた後，試 料の重量を測定した。含水率の算出式は以下の式を用い た。

含水率 $(\%)=$ (乾燥前の試料重量 $(\mathrm{g})-$ 乾燥後 の試料重量 $(\mathrm{g}))$ / 乾燥前の試料重量 $(\mathrm{g}) \times 100$ なお測定は，各試料10回ずつ繰り返し行った。

\section{4 ) 溶出固形物}

粥液3. $0 \mathrm{~g}$ を $105^{\circ} \mathrm{C}$ に設定した恒温槽（DO-600FA，ア ズワン(株) を用いて24時間乾燥させた後, 試料の重量を 測定した。溶出固形物の算出式は以下の式を用いた。

溶出固形物の割合 $(\%)=$ 乾燥後の試料重量 $(\mathrm{g}) /$ 乾燥前の試料重量 $(\mathrm{g}) \times 100$

なお測定は，乾燥後の重量が少量であると予想された ため, 各試料10回ずつ繰り返し行った。

5 ) アミロース

試料は粥と分離して得た粥飯の 2 種類用意した。分析 には，凍結乾燥した試料をミルミキサー（フォースミル FM-1，アズワン(株)）で十分に粉砕し，目開き $100 \mu \mathrm{m}$ のふるいを通過した乾燥粉末を用いた。また，実験に使 用した生米に含まれるアミロース量を測定するため，生 米を同様な手法を用いて調製した乾燥粉末を準備した。

アミロースの定量には，簡易比色定量 ${ }^{23)}$ を適用した。 乾燥粉末 $0.05 \mathrm{~g}$ に $95 \%$ エタール $0.5 \mathrm{~mL}, 1 \mathrm{~N} \mathrm{NaOH} 4.5 \mathrm{~mL}$ を加え沸騰水中で10分加熱した後, 蒸留水で50 mL に希 釈した。希棌液は $2.5 \mathrm{~mL}$ 分注した後, $1 \mathrm{~N}$ 酢酸 $0.5 \mathrm{~mL}$ ヨウ素・ ヨウ化カリウム溶液 $1.0 \mathrm{~mL}$ を加えて $50 \mathrm{~mL}$ に 定容し， $30^{\circ} \mathrm{C}$ に設定した恒温槽で20分静置した。この溶 液を, 分光光度計 (ASV11D-H，アズワン(株) を用いて 波長 $620 \mathrm{~nm}$ の吸光度を測定し, 乾燥粉末 $1.0 \mathrm{~g}$ あたりの アミロース量に換算した。標準物質には標準アミロース （ポテトアミロース Type III， SIGMA）を用いた。また 調理終了時の粥の重量, 粥と粥飯の含水率, 继液の割合 および測定した粥と粥飯のアミロース量から，粥液 $1.0 \mathrm{~g}$ 中に含まれるアミロース量を推算した。なおこの際, 平均值を用いて算出した。測定は, 各試料 4 回ずつ繰り 返し行った。

\section{6 ）還 元 糖}

試料は粥と分離して得た濑飯の 2 種類用意した。分析 には，凍結乾燥した試料をミルミキサー（フォースミル FM-1，アズワン(株)）で十分に粉砕し，目開き $100 \mu \mathrm{m}$ のふるいを通過した乾燥粉末を用いた。

還元糖の定量には,ソモギ・ネルソン法 ${ }^{24)}$ を適用した。
乾燥粉末 $0.5 \mathrm{~g}$ に $50 \%$ エタノールを加え， $25^{\circ} \mathrm{C}$ で 1 時間 振とう抽出した後, 遠心分離 $(5,000 \mathrm{rpm}, 30$ 分）を施し, 上澄み液を得た。この上澄み液 $1.0 \mathrm{~mL}$ にソモギ試薬 $1.0 \mathrm{~mL}$ を加え, 沸騰水中で10分間加熱し, 冷却後にネ ルソン試薬 $1.0 \mathrm{~mL}$, 蒸留水 $2.0 \mathrm{~mL}$ を加えた。この溶液を, 分光光度計 (ASV11D-H, アズワン(株) を用いて波長 $520 \mathrm{~nm}$ の吸光度を測定し, 乾燥粉末 $1.0 \mathrm{~g}$ あたりの還元 糖量に換算した。標準物質にはグルコース（無水ぶどう 糖, 関東化学(株)）を用いた。また, 調理終了時の粥の重 量, 粥と粥飯の含水率, 断液の割合および測定した粥と 粥飯の還元糖の量から, 粥液 $1.0 \mathrm{~g}$ 中に含まれる還元糖 の量を推算した。なおこの際, 平均值を用いて算出した。 測定は, 各試料 4 回ずつ繰り返し行った。

\section{7 ）破断応力の測定}

岸本 ${ }^{25)}$ ，冨田 ${ }^{26)}$ の測定方法を参考とし，嗽飯 1 粒 の破断応力を測定した。粥飯 1 粒を卓上型物性試験測定 器（TPU- $2 \mathrm{LD}$, (株)山電) の試験台に横に置き, くさび 形プランジャー（接触面積 $2.0 \mathrm{~mm}^{2}$ ) を使用して, ひず み率 $100 \%$, 圧縮速度 $1.0 \mathrm{~mm} / \mathrm{sec}$ で定速 1 回圧縮測定 を行った。測定は個体差が大きいことを考慮し, 各試料 15回ずつ繰り返し行った。

\section{(4) 統計処理}

結果はすべて平均值と標準偏差（SD）で示し, 統計 処理にはエスミ Excel 統計 Ver7.0を使用した。加熱条 件の違いについて一元限配置分散分析を行い，その後ボ ンフェローニの多重比較検定を行った（ $p<0.01 ）$ 。また アミロースと還元糖の含有量は，同じ加熱条件における 继と粥飯についても同様な検定を行った $(p<0.01)$ 。

\section{3. 結果および考察}

\section{（1）温度履歴および糊化度}

3 種類の加熱条件における温度履歴を Fig. 1 に示す。 「鍋」は加熱開始から約 6 分後に最高温度である $97.5 \pm$ $0.4{ }^{\circ} \mathrm{C}$ まで上昇し, 弱火で加熱した 40 分間は $95^{\circ} \mathrm{C}$ 前後を

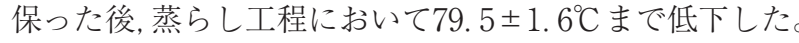
「炊飯器」は炊飯開始から約 40 分かけて $100^{\circ} \mathrm{C}$ 付近まで上 昇し, 炊飯終了まで $98^{\circ} \mathrm{C}$ 前後を保っていた。「炊飯器 + 鍋」 は炊飯開始から約 20 分かけて $60^{\circ} \mathrm{C}$ 付近まで一定の速度で 温度上昇し， $95^{\circ} \mathrm{C}$ 付近まで著しく上昇した後は炊飯終了 まで $95^{\circ} \mathrm{C}$ 前後を保っていた。炊飯終了後, 直ちに米飯を 鍋に移し, 水を $800 \mathrm{~g}$ 加えて加熱を開始すると, 加熱開 始から 5 分半かけて $94^{\circ} \mathrm{C}$ 付近まで上昇し, 10 分間 $90^{\circ} \mathrm{C}$ 前 後を保った後, 蒸らし工程において $79.1 \pm 1.6^{\circ} \mathrm{C}$ まで低 下した。

調理終了時の糊化度は,「鍋」は95. $5 \pm 1.7 \%$,「炊飯器」

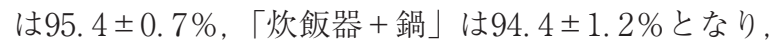
有意な差は確認されなかった。デンプンが糊化するため には, 水と加熱が必要となる。加水量は通常の米飯より も多く，かつすべての加熱条件が米デンプンの糊化温度 

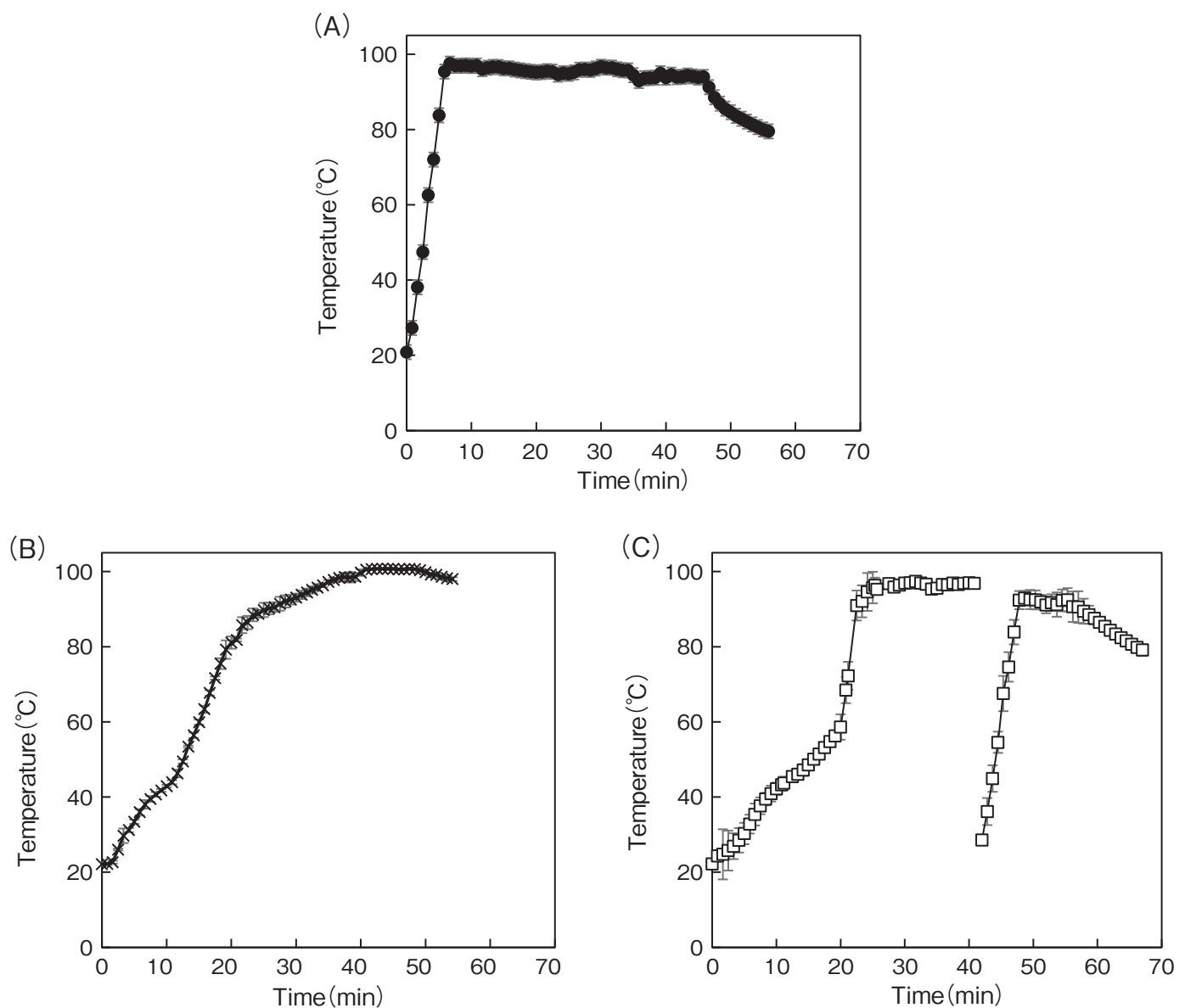

Figure 1 Temperature history during cooking process $(n=5)$

(A) rice in a pot, (B) using the rice porridge mode on a rice cooker, $(\mathrm{C})$ cooked rice in a pot.

帯である $62 \sim 67^{\circ} \mathrm{C}^{27)}$ を40分以上保っていたことから，糊 化度に有意な差がみられなかったと考えられる。また, 離乳食に含まれるデンプンの糊化度は $80 \%$ 以上と定めら れているが28)，本実験で調理した粥はすべて基準を満た していることが確認された。

（2）調理終了時の重量, 含水率, 溶出固形物, アミロー

\section{スおよび還元糖含有量}

調理終了時の㑛を観察すると,「炊飯器 + 鍋」の坫飯 はその他の粥飯と比較すると最も形状を保っており, 粥 液はさらさらしていた。これに対して「炊飯器」の䉼飯 の表面は崩れており, 粥液のとろみが強かった。

Table 1 に, 各調理に使用した米と水の分量, 調理終了 時の粥の重量, 分離した際の粥液の割合, 断液に溶出し た固形物の割合，继および粥飯の含水率を示した。

調理終了時の重量は,「鍋」は698.8 $\pm 3.0 \mathrm{~g}$,「炊飯器」 は792. $9 \pm 4.8 \mathrm{~g}$, 「炊飯器 + 鍋」は913. $0 \pm 8.4 \mathrm{~g}$ と有意 な差が確認された $(p<0.01)$ 。鍋」と「炊飯器」は, 調理に用いた生米の重量 $75 \mathrm{~g}$ に対して 10 倍量の $750 \mathrm{~g}$ の 水を使用したのに対し,「炊飯器 + 鍋」は, 炊飯器で炊 きあがった米飯の重量 $160.2 \pm 2.8 \mathrm{~g}$ に対する 5 倍量の水 $800 \mathrm{~g}$ を加えたことや, 鍋で加熱する時間は15分半と他 の加熱条件よりも短いため蒸発量が少なくなり, 調理終
了時の重量が最も重くなったと考えられる。また「炊飯 器」と「鍋」は同じ加水量であるが，炊飯器は鍋よりも 蒸発しにくい調理器具であるため, 蒸発量が抑制された と考えられる。分離後の继液の割合は「炊飯器 + 鍋」の $37.6 \pm 6.7 \%$ が最も高く,「鍋」,「炊飯器」と続いた（ $<0.01) 。 こ れ に$ 対して粥液に溶出した固形物の割合は, 「炊飯器」の $4.4 \pm 0.1 \%$ が最も高く, 次いで「鍋」,「炊 飯器 + 鍋」となった $(p<0.01)$ 。粥の含水率は加熱条 件の違いによる有意な差はみられず，すべての加熱条件 で約 $91 \%$ となったが, 粥飯の含水率は「炊飯器」が他の 加熱条件よりも有意に高くなった $(p<0.01)$ 。「炊飯器」 の洂液はとろみが強く, 粥飯にまとわりついたため粥飯 の含水率が最も高くなったと考えられる。

ところで, 米飯の粘りや吸水性にはアミロースが関与 すること ${ }^{7,29,30)}$, 米飯の加熱時に液中に溶出する固形物 には米粒表面から剥離した組織細胞やデンプン ${ }^{30)}$, そし て還元糖の生成が関与することが知られている ${ }^{31}$ 。前述 した粥と张液の性状の違いは，これらの量に由来すると

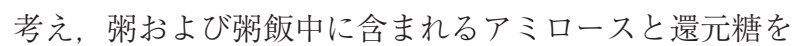
測定した。

実験に使用した生米に含まれるアミロース量は193. 3 $\pm 4.8 \mathrm{mg} / \mathrm{g}_{\text {dry sample }}$ となり, 大島ら ${ }^{31)}$ が定量した搗精後の コシヒカリに含まれるアミロース量とほぼ等しいことを 
Table 1 Quantity of materials, separation experiment, and the measurement of moisture content

\begin{tabular}{|c|c|c|c|c|}
\hline & \multirow{2}{*}{ pot } & \multirow{2}{*}{ rice cooker } & \multicolumn{2}{|c|}{ rice cooker and pot } \\
\hline & & & process of rice cooker & process of pot \\
\hline Raw rice $(\mathrm{g})$ & 75.0 & 75.0 & 75.0 & - \\
\hline Cooked rice $(\mathrm{g})$ & - & - & - & $160.2 \pm 2.8$ \\
\hline Water $(\mathrm{g})$ & 750.0 & 750.0 & 112.0 & 800.0 \\
\hline Weight in the end of the cooking $(\mathrm{g})$ & $698.8 \pm 3.0^{c}$ & $792.9 \pm 4.8^{\mathrm{b}}$ & $(160.2 \pm 2.8)$ & $913.0 \pm 8.4^{\mathrm{a}}$ \\
\hline Ratio of rice porridge liquid (\%) & $21.4 \pm 3.0^{\mathrm{b}}$ & $14.5 \pm 3.6^{\mathrm{c}}$ & - & $37.6 \pm 6.7^{\mathrm{a}}$ \\
\hline $\begin{array}{l}\text { Ratio of eluted substance contained in the } \\
\text { rice porridge liquid (\%) }\end{array}$ & $4.1 \pm 0.2^{\mathrm{b}}$ & $4.4 \pm 0.1^{\mathrm{a}}$ & - & $2.9 \pm 0.2^{\mathrm{c}}$ \\
\hline Moisture content of rice porridge $(\%)$ & $90.2 \pm 0.9^{\text {n.s. }}$ & $90.5 \pm 0.7^{\mathrm{ns.s}}$ & - & $91.7 \pm 1.0^{\text {n.s. }}$ \\
\hline Moisture content of rice grain (\%) & $87.0 \pm 0.5^{\mathrm{b}}$ & $89.3 \pm 0.6^{\mathrm{a}}$ & - & $86.9 \pm 0.6^{b}$ \\
\hline
\end{tabular}

Values are mean $\pm \mathrm{SD}(n \geqq 5)$.

Different letters within the same row are significant difference $(p<0.01)$.

n.s.: There was not the significant difference $(p>0.01)$.

Table 2 Measurement of amylose in the rice porridge and rice grain

\begin{tabular}{|c|c|c|c|}
\hline & pot & rice cooker & rice cooker and pot \\
\hline rice porridge $\left(\mathrm{mg} / \mathrm{g}_{\text {-dry sample }}\right)$ & $195.8 \pm 5.6^{\text {n.s. }}$ & $192.6 \pm 4.5^{\text {n.s. }}$ & $190.9 \pm 5.2^{\text {n.s. }}$ \\
\hline rice grain $\left(\mathrm{mg} / \mathrm{g}_{\text {dry sample }}\right)$ & $184.6 \pm 4.9^{\text {n.s. }}$ & $189.5 \pm 5.8^{\text {n.s. }}$ & $188.4 \pm 3.0^{\text {n.s. }}$ \\
\hline Estimated concentration of amylose in the rice porridge liquid $(\mathrm{mg} / \mathrm{g})$ & 1.52 & 6.62 & 1. 18 \\
\hline
\end{tabular}

Values are mean $\pm \mathrm{SD}(n=4)$.

n.s.: There was not the significant difference $(p>0.01)$.

Estimated value was calculated using average of the experimental values.

Table 3 Measurement of reducing sugar in the rice porridge and rice grain

\begin{tabular}{lccc}
\hline & pot & rice cooker & rice cooker and pot \\
\hline rice porridge $\left(\mathrm{mg} / \mathrm{g}_{\text {-dry sample }}\right)$ & $4.3 \pm 0.2^{\mathrm{cx}}$ & $6.5 \pm 0.2^{\text {bx }}$ & $7.0 \pm 0.1^{\text {ax }}$ \\
rice grain $\left(\mathrm{mg} / \mathrm{g}_{\text {-dry sample }}\right)$ & $2.7 \pm 0.1^{\mathrm{cy}}$ & $3.6 \pm 0.1^{\text {by }}$ & $4.8 \pm 0.1^{\text {ay }}$ \\
$\begin{array}{l}\text { Estimated concentration of reducing } \\
\text { sugars in the rice porridge liquid }(\mathrm{mg} / \mathrm{g})\end{array}$ & 0.68 & 1.99 & 0.50 \\
\hline
\end{tabular}

Values are mean $\pm \mathrm{SD}(n=4)$.

abc: Different letters within the same row are significant difference $(p<0.01)$.

${ }^{\mathrm{xy}}$ : Different letters within the same column are significant difference $(p<0.01)$.

Estimated value was calculated using average of the experimental values.

確認した。次に，粥と分離して得た粥飯中に含まれるア ミロースの量を Table 2 に示す。すべての加熱条件にお いて, 粥は $190 \mathrm{mg} / \mathrm{g}_{\text {-dry sample }}$ 前後, 粥飯には $187 \mathrm{mg} / \mathrm{g}_{\text {-dry sample }}$ 前後のアミロースが含まれていたが，粥，继飯の両方に おいて加熱条件の違いによる有意な差はみられなかった。 また, 調理前の生米と 3 種類の加熱条件で調理した悚の すべてにおいても，アミロース量に有意な差はみられな かった。精白米のデンプンは, アミロースとアミロペク チンから構成されており，アミロース量は米の品種に依 存する ${ }^{7)}$ 。本研究は共通の生米を実験に使用したため, 10倍彈与粥飯の両方において加熱条件の違いによる差が みられなかったと推察される。しかし，アミロースは米
飯の粘りや粥液の性状に影響することが報告されている ことから ${ }^{7,29,30)}$, 粥液 $1.0 \mathrm{~g}$ に含まれるアミロースの量を 推算した。その結果, 粥液 $1.0 \mathrm{~g}$ 中に含まれるアミロー スの推算值は, 「炊飯器」,「鍋」,「炊飯器 + 鍋」の順に 多く, 粥液に溶出した固形物の割合が高い順番と同じ だった。またアミロース含有量が高くなるに従い粥液の 流動性指数は低くなることから ${ }^{7)}$ ，今回推算した結果は， 調理終了時の粥の性状と一致することが確認された。

次に，粥および彇飯に含まれる還元糖の量を Table 3

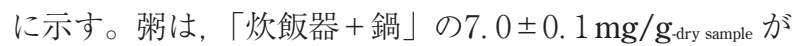
最も多く, 次いで「炊飯器」,「鍋」と続いた。粥飯にお いても，含有量の高い順番は继と同様であり，粥，粥飯 
日本食生活学会誌 Vol.32 No.1（2021）

Table 4 Effect of the heating condition on the breaking stress and strain of rice grain

\begin{tabular}{lrrc}
\hline & pot & \multicolumn{1}{c}{ rice cooker } & rice cooker and pot \\
\hline Breaking stress $\left(\mathrm{N} / \mathrm{m}^{2}\right)$ & $501.1 \pm 32.8^{\mathrm{b}}$ & $333.3 \pm 20.9^{\mathrm{c}}$ & $591.2 \pm 45.9^{\mathrm{a}}$ \\
Breaking strain $(\%)$ & $82.2 \pm 1.6^{\text {n.s. }}$ & $81.9 \pm 2.0^{\text {n.s. }}$ & $81.1 \pm 1.9^{\text {n.s. }}$ \\
\hline
\end{tabular}

Values are mean \pm SD $(n=15)$.

Different letters are significant difference $(p<0.01)$.

n.s: There was not the significant difference $(p>0.01)$.

ともに加熱条件の違いによって，含有量は有意に異なる ことが明らかとなった $(p<0.01)$ 。還元糖の生成はア ミラーゼやグルコシダーゼなどの各種デンプンの分解酵 素の活性に依存しており，600 $\mathrm{C}$ 付近で最大となったのち， $70^{\circ} \mathrm{C}$ 以上ではほぼ失活する ${ }^{32-34}$ 。Fig. 1 に示した温度履 歴より，「鍋」は加熱開始から約 4 分後に失活温度带で ある $70^{\circ} \mathrm{C}$ に到達しため，還元糖の量が最も少なくなった と考えられる。これに対して, 炊飯器を利用した加熱条 件は $70^{\circ} \mathrm{C}$ に到達するまで20分前後の時間を要したため,

「鍋」よりも還元糖が多くなったと推察される。しかし 「炊飯器 + 鍋」の䉼液中の溶出固形物の割合は2. $9 \pm 0.2 \%$ と最も低く（Table 1)，ささらさらとした性状とは相反す る結果を示した。これは調理終了時の重量の違いに由来 すると考元，粥液 $1.0 \mathrm{~g}$ に含まれる還元糖の量を推算した。 その結果, 弲液 $1.0 \mathrm{~g}$ 中に含まれる還元糖の推算值は, 「炊 飯器」が $1.99 \mathrm{mg} / \mathrm{g}$ と最も多く, 次いで「鍋」「炊飯器 十鍋」と続き，今回推算した結果は，アミロースの含有 量と同様に，調理終了時の张の性状と一致した。

\section{（3）粥飯の破断応力測定}

Table 4 に粥飯 1 粒の破断応力と破断ひずみの測定結 果を示す。「炊飯器 + 鍋」は591.2 $2 \pm 45.9 \mathrm{~N} / \mathrm{m}^{2}$ と本加熱 条件の中で最も高い値となったが，岸本ら ${ }^{25}$ が報告して いる米飯 1 粒の破断応力の值 (約 $\left.630 \mathrm{~N} / \mathrm{m}^{2}\right)$ よりも低 かった。これは，本研究では離乳食に使用する粥を対象 としているため，炊飯器で炊いた米飯に加水し，鍋で加 熱する工程が加わっていることが原因として挙げられる。 また，加熱条件の違いは破断応力の值が有意に異なり， 「炊飯器 + 鍋」,「鍋」, 「炊飯器」の順に粥飯がかたいこと が明らかとなった $(p<0.01)$ 。啹飯は $100^{\circ} \mathrm{C}$ に近い温度带

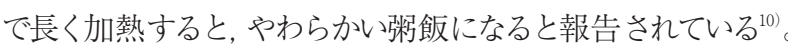
「炊飯器 + 鍋」も $90^{\circ} \mathrm{C}$ 付近の温度帯で加熱する工程が含 まれているが，他の加熱条件で $90^{\circ} \mathrm{C}$ 以上を保っていた時 間よりも短かったため，粥飯の軟化が抑制されたと考え られる。しかし破断ひずみは 3 種類すべての柅飯におい て $82 \%$ 前後で破断しており，有意な差はみられなかった。 冨田ら ${ }^{26)}$ は炊く前に生米を浸漬することで，破断ひずみ は低くなること, 浸漬過程の吸水量がほぼ等しい米飯の 破断ひずみは大きな差がないことを報告している。本研 究で測定した試料は，すべて加熱を施す前に30分間浸漬 させており，浸漬時の吸水量が等しいため，柅飯の破断 ひずみに有意な差がなかったと推察される。

\section{（4）继の特徵}

各加熱条件の粥の特徵は以下のようにまとめられる。

「鍋」は, 調理終了時の弱の重量が最も少なかった。 また, デンプン分解酵素の失活温度帯である $70^{\circ} \mathrm{C}$ に最も 早く到達したため, 還元糖の生成量は最も少なかった。

「炊飯器」は，最もとろみのある粥だった。これは粥 液中のアミロースや還元糖の濃度が最も高いことが原因 として挙げられる。また，最もやわらかい愺飯だった。

「炊飯器 + 鍋」は, 通常の分量で炊いた米飯に, 加水し, 鍋で加熱する方法である。米飯に加えた水は $800 \mathrm{~g}$ と他 の方法よりも多い点や，鍋で加熱する時間が他の方法よ りも短いため, 調理終了時の粥の重量が最も重くなった。 また，柅液中の溶出固形物，アミロースそして還元糖の 濃度が最も低いため, 濑の性状は最もさらさらとしてい たが，㑛飯はかたかった。

以上のように, 今回対象とした加熱条件はすべて離乳 開始時の10倍张を想定した方法であるにもかかわらず， 調理終了時の性状やかたさが異なることが明らかとなっ た。粥の品質に影響を及ぼす大きな要因として 3 点に整 理できる。1点目は生米を加熱する際の温度履歴の違い である。生米の鍋による調理と炊飯器を利用した調理で は, 還元糖の生成に関与する酔素の失活温度帯までに要 する時間や，酵素活性が最大となる $60^{\circ} \mathrm{C}$ の滞在時間は異 なる。また炊飯器を利用した場合でも，白米モードやお 粥モードなど，利用するモードによって温度履歷が異な るため, 還元糖の生成量は 3 種類の加熱条件で有意に異 なることが明らかとなった。2 点目は加水量の違いであ る。「炊飯器十鍋」は他の加熱条件よりも加水量が多い ため，還元糖の量は最も多いにもかかわらず柅液中の濃 度に換算すると濃度が低くなり，最もさらさらとした性 状となった。 3 点目は加水するタイミングである。炊い た米飯に水を加え加熱を施しても，デンプンの糊化はす でに完了しているため, デンプンの吸水性は低下してい る。すなわち，鍋で米飯を加熱する工程では溶質量は炊 飯器の工程終了時から増加しないが, 加水によって溶媒 が著しく増加したと考えられ，その結果，分離後の䐖液 の割合は「炊飯器十鍋」が最も高くなったと推察される。 本研究では各加熱条件で 1 種類の加水量のみを検証し ており，同じ加熱条件において加水量の違いによる品質 の差異まで検証を行っていない。また，鍋で加熱する工 程では加水量のみならず，加熱時間の違いが性状や柅飯 のかたさに影響を及ぼすことは明白であり ${ }^{6,10,12)}$ ，今回 
最もさらさらとした性状となった「炊飯器＋鍋」につい ても，鍋の工程における加熱時間を長くすることで，他 の加熱条件の品質に近くなる可能性を有している。さら には, 本研究では品質測定時の試料温度をユニバーサル デザインフード自主規格 ${ }^{21}$ を参考とし $20^{\circ} \mathrm{C}$ とたが，乳 児が契食するのに適した温度帯は人肌程度であると考え られる。また，さらさら/どろどろといった粥液の性状 を反映した粘度は， $20^{\circ} \mathrm{C}$ と喫食時，さらには口腔内の温 度 $\left(\right.$ 約 $\left.37^{\circ} \mathrm{C}\right)$ において異なること予想されるため, 今後, 各加熱条件で加水量や加熱時間，そして試料温度の違い による品質の差異について測定し, 整理することが課題 として挙げられる。今後, これらの加熱条件によって調 製された試料を対象とし，つぶした後のかたさや粘度等

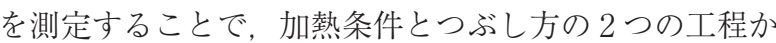
ら離乳食の品質に及ぼす影響について整理する予定であ る。

\section{4. 結 論}

本研究は，現在の離乳食（10倍继）作りで利用されて いる割合が高い，「生米を鍋で調理する」，「炊飯器のお 粥モードで炊く」,「炊飯器で炊いたご飯を鍋で調理する」 の 3 種類の加熱条件を対象とし, 含水率, 溶出固形物, 破断応力等を分析した。その結果，今回調理したすべて の粐は離乳食で規定されている糊化度 $80 \%$ 以上を満たし ていることを確認したが，離乳開始時に用いる10倍粥を 対象とした調理方法であるにもかかわらず，生米を加熱 する際の温度履歴, 加水量, そして加水するタイミング が異なるため, 調理終了時の性状や粥飯のかたさが異な ることが明らかとなった。

\section{謝辞}

本研究は, 平成31年度公益信託 家政学研究助成基金 の支援により実施した。また，本研究にご協力いただき ました岐皁大学応用生物科学部 西津貴久先生, 宇都宮 大学農学部 田村匡嗣先生, 実験補助をしてくださいま した藤根悦子様に心より感謝申し上げます。

\section{文献}

1) 厚生労働省：令和元年（2019）人口動態統計（確定数） の概況 (2020/9/17), https://www.mhlw.go.jp/toukei/saikin /hw/jinkou/kakutei19/dl/02_kek.pdf (2020/11/18)

2 ）総務省統計局：平成 27 年国勢調査 世帯構造等基本集計 結果 (2017/ 9 /27), https://www.stat.go.jp/data/kokusei/ 2015/kekka/kihon 3 /pdf/gaiyou.pdf (2020/ 3 / 3 )

3 ) 総務省統計局：労働力調査 (基本集計) 2019年 (令和元年) 平均結果, https://www.stat.go.jp/data/roudou/sokuhou/ nen/ft/pdf/index.pdf (2020/ 3 / 3 )

4 ）厚生労働省：平成27年度乳幼児栄養調査結果の概要 (2015), https://www.mhlw.go.jp/file/06-Seisakujouhou-11900000-Koy oukintoujidoukateikyoku/0000134460.pdf (2020/ 2 /28)

5 ) 柴田（石渡）奈緒美，梅村詩音：離乳食の調理方法に関 するアンケート調査〜現在と 20 年前の10倍柭の調理方法に
ついて〜，日本調理科学会誌， 53，25-33，(2020)

6 ）江間章子，貝沼やす子：粥の調理に関する研究（第 2 報 加熱条件が全张の性状に及ぼす影響，日本家政学会誌， 48, 391-398（1997）

7 ）高橋智子, 河村彩乃, 大越ひろ：アミロース含有率の異 なる米を用いた粥の力学的特性と口中感覚, 咀嚼筋電位, 日本調理科学会誌，46，196-204（2013）

8 ）田口郁栄, 伊藤裕子, 白男川太一, 増田邦子, 大越ひろ 高橋智子：真空調理粥㧍よびレトルト㑛から調製した食べ やすいブレンダー继の調製条件の検討，栄養学雑誌，68, 201-207 (2010)

9）貝沼やす子：米の調理性に関する研究，日本家政学会誌， 60, 775-783 (2009)

10）貝沼やす子：真空調理法による粥調製方法の検討，日本 家政学会誌，59，825-835（2008）

11）岡澤仁志, 小西宏和, 吉田智洋, 勝又明敏, 飯田幸弘, 藤下昌己：嚥下障害患者に対する食品としてのお粥の特性, 岐阜歯科学会雑誌，35，7-12（2008）

12）貝沼やす子：加水量が異なる米飯から調製した粥の性状, 日本家政学会誌，57，199-207（2006）

13）江間章子, 貝沼やす子：粥の調理に関する研究（第 4 報） 調理後の経過時間㧍よび保温条件が荆の性状に及ぼす影響, 日本家政学会誌，51，571-578（2000）

14）江間章子, 貝沼やす子：粥の調理に関する研究（第 3 報） 鍋の材質および加熱条件が全粥の性状に及ぼす影響，日本 家政学会誌，50，341-347（1999）

15）鈴野弘子, 鈴木恵子, 石田裕, 笹田陽子：要介護高齢者 施設に抢ける食物形態の実態とその物性評価, 日本家政学 会誌，63，469-480（2012）

16）森崎友紀：ママがんばらないで離乳食, トランスワール ドジャパン, 東京, p.15（2018）

17）堤ちはる, 新原恵子：いちばんやさしきほんの離乳食, 成美堂出版，東京，p.28（2010）

18）パルシステム生活協同組合連合会 : pal· system 子育て123 ご飯から鍋で作る10倍がゆ, https://kosodate.pal-system. co.jp/recipe/recipe_367/(2019/1/30)

19）オールアバウト：All About 暮らし 離乳食の扔かゆ! 10 倍弱の作り方・レシピ, https://allabout.co.jp/gm/gc/303246/ (2019/2/ 5 )

20） 主婦の友社：Baby-mo 離乳食をラクに! 楽しく!，主婦 の友社，東京，p.72（2018）

21）日本介護食品協議会：日本介護食品協議会コーナー ユ ニバーサルデザインフード（UDF）「かたさ」測定法の検証 缶詰時報 1 月号，90，71-73（2011）

22）大田朋槻, 松島紋子, 中山清貴, 赤崎哲也：税関分析法「で ん粉のアルファー化度の測定方法」の改善，関税中央分析 所報, 54, 5-12 (2015)

23) Juliano B.O.: A simplified assay for milled rice amylose, Cereal Science Today, 16, 334-360 (1971)

24）目黑熙, 西田芳明：新・食品成分法, 光琳, 東京, pp.528-564 (1997)

25）岸本律子，長谷川悦子，中嶋加代子，森光寿，地上博子： 紫黑米混合飯の色調と物性に与える有機酸の影響, 日本調 理科学会誌，46，107-113（2013）

26）冨田晴雄, 坂本薰, John Henderson, 竹森利和：浸漬時 間の違いによる米飯の構造とテクスチャーの関係，日本調 理科学会誌，48，18-25（2015）

27）山崎清子, 島田キミエ, 渋川祥子, 下村道子：新版 調 
理と理論，同文書院，東京，pp.51-52（2007）

28）厚生労働省生活衛生局：ベビーフード指針について (1996), https://www.mhlw.go.jp/www 1 /houdou/0806/ 0626- 1 .html $(2020 / 2 / 28)$

29）家村芳次, 影山由香里, 松永恒司, 原昌道：アミロース 含量，心白および腹白が白米の吸水性に及ぼす影響，日本 醸造協会史，91，515-520（1996）

30）花城勲, 太田健介, 武田千重乃, 水上浩之, 竹田靖史： 炊飯時に溶出する澱粉成分の構造と米飯の付着性, Journal of applied glycoscience, 51，349-354（2004）

31）大島誉章, 田村匡嗣, 井坂亜由美, 小川幸春：炊飯過程 に扮ける米粒含有成分・含有量の変化, 美味技術学会誌,
11, 22-28 (2012)

32）馬場由佳：炊飯過程における米内在性酵素の米飯食味へ の関与， 日本調理科学会誌，42，369-377（2009）

33）香西みどり, 石黒恭子, 京田比奈子, 浜薗貴子, 畑江敬子, 島田淳子：米の炊飯過程における還元糖および遊離アミノ 酸量の変化，日本家政学会誌，51，579-585（2000）

34) Motoko Awazuhara, Atsuko Nakagawa, Junji Yamaguchi, Toru Fujiwara, Hiroaki Hayashi, Keiko Hatae, Mitsuo Chino, Shimada Atsuko: Distribution and Characterization of Enzymes Responsible for Starch Degradation in Rice (Oryza sativa Cv. Koshihikari), J. Agric. Food Chem., 48, 245-252 (2000) 